\title{
Exosomes and Microvesicles: from Stem Cell Biology to Translation in Human Diseases
}

\author{
Giovanni Camussi ${ }^{1}$ \\ Published online: 28 January 2022 \\ (c) The Author(s), under exclusive licence to Springer Science+Business Media, LLC, part of Springer Nature 2022
}

Exosomes/microvesicles also known as extracellular vesicles emerged as a well evolutionary preserved cell-to-cell communication mechanism [1]. The first recognition that stem cells may communicate through vesicles [2] was followed by several studies showing the role of extracellular vesicles in stem cell biology [3, 4]. Moreover, it has been shown that stem cell-derived vesicles may mimic the biological activity of the stem cells of origin and that they represent a relevant element of the paracrine action of stem cells. These observations served as the rational for several studies aimed to exploit the potential therapeutical activity of stem cellderived vesicles in different pathological conditions. The biological active vesicles represent a heterogeneous population which differentially expresses the regenerative properties as seen by the analysis of sub-population fractions [5]. The mechanism of action of stem/progenitor cell-derived vesicles has been related to the transfer of transcripts that may modulate selected pathways in the recipient cells inducing epigenetic, functional, and phenotypic changes in the latter $[2,6]$.

The present special issue of Stem Cell Reviews and Reports is focused mainly on the cargo and on selected transcripts carried by vesicles released by mesenchymal stem cells of different origin. In particular, these transcripts appeared to be relevant for the immunomodulatory/antiinflammatory and regenerative properties of stem cellderived vesicles in a variety of pathological conditions including diabetes, kidney, liver, bone, and spinal cord injuries.

\section{References}

1. Ratajczak, J., Wysoczynski, M., Hayek, F., et al. (2006). Membrane-derived microvesicles: Important and underappreciated mediators of cell-to-cell communication. Leukemia, 20(9), 14871495. https://doi.org/10.1038/sj.leu.2404296

2. Ratajczak, J., Miekus, K., Kucia, M., et al. (2006). Embryonic stem cell-derived microvesicles reprogram hematopoietic progenitors: Evidence for horizontal transfer of mRNA and protein delivery. Leukemia, 20(5), 847-856. https://doi.org/10.1038/sj. leu. 2404132

3. Bruno, S., Chiabotto, G., Favaro, E., et al. (2019). Role of extracellular vesicles in stem cell biology. American Journal of Physiology-Cell Physiology, 317(2), C303-C313. https://doi.org/10. 1152/ajpcell.00129

4. Hur, Y. H., Cerione, R. A., \& Antonyak, M. A. (2020). Extracellular vesicles and their roles in stem cell biology. Stem Cells, 38(4), 469-476. https://doi.org/10.1002/stem.3140

5. Collino, F., Pomatto, M., Bruno, S., et al. (2017). Exosome and Microvesicle-Enriched Fractions Isolated from Mesenchymal Stem Cells by Gradient Separation Showed Different Molecular Signatures and Functions on Renal Tubular Epithelial Cells. Stem Cell Reviews and Reports, 13(2), 226-243. https://doi.org/ 10.1007/s12015-016-9713-1

6. Deregibus, M.C., Cantaluppi, V., Calogero, R., et al. Endothelial progenitor cell derived microvesicles activate an angiogenic program in endothelial cells by a horizontal transfer of mRNA. Blood, 110(7):2440-8. https://doi.org/10.1182/blood-2007-03-078709

Publisher's Note Springer Nature remains neutral with regard to jurisdictional claims in published maps and institutional affiliations.

Giovanni Camussi

giovanni.camussi@unito.it

1 Department of Medical Sciences, University of Turin, Turin, Italy 